ГЛОБАЛЬНІ ПРИНЦИПИ УПРАВЛІНСЬКОГО ОБЛІКУ ТА ЇХ ЗАСТОСУВАННЯ НА ПІДПРИЕМСТВАХ

\author{
ЛЕПЕТАН I.М., \\ кандидат економічних наук, \\ доцент кафедри бухгалтерського \\ обліку, \\ Вінницький національний \\ аграрний університет \\ (м. Вінниця)
}

У статті розкрито перелік та сутність принциипів бухгалтерського обліку та зосереджено увагу на приниипах саме управлінського обліку, оскільки не всі загальноприйняті принципи бухгалтерського обліку підходять для застосування в управлінському обліку. Систематизовано основні принципи управлінського обліку з об'єднанням за різними аспектами, щуо виділені різними науковиями.

Більш детально розкрито Глобальні принципи управлінського обліку, які розроблені міжнародними організачіями та визначають передову практику бухгалтерського обліку, яка сприяє прийняттю складних рішень, щзо забезпечують сталу ијінність.

У статті описано складові принщипів та шляхи їх застосування. Приділено увагу принцииу «Комунікація породжує інформацію, щчо має вплив», який означає, щчо управлінський облік починається $i$ завершується спілкуванням. Основною метою цього принципу $\epsilon$ прийняття ефективних рішень про стратегію і ї̈ реалізацію на всіх рівнях.

Принции «Інформація є релевантною» спрямовує управлінський облік на забезпечення керівників релевантною інформацією тоді, коли це необхідно, виявляє минулу, поточну, майбутню інформацію, зокрема фінансові та нефінансові дані з внутрішніх $i$ зовнішніх джерел. Сюди входять соціальні, екологічні та економічні дані. Метою изього принщипу $\epsilon$ надання підприємству інформаційної підтримки при плануванні та розробиі стратегії, тактики і їхньої реалізації.

Принцииом «Аналізується вплив на вартість» управлінський облік ув'язує стратегію організаиї з ї̈ бізнес-моделлю. Цей принцип допомагає опраџьовувати різні сценарії з метою розуміння їхнього впливу на створення та збереження вартості. Основною метою иього принцииу є моделювання різних сиенаріїв, щзо демонструють причинно-наслідкові зв'язки між чинниками діяльності і результатами.

Мета принщипу «Розумне керування вибудовує довіру» сформульована як необхідність активно управляти відносинами та ресурсами для захисту фінансових і нефінансових активів компанії, іï репутації та вартості.

Звернено увагу на основні компетенції, якими повинні володіти спеціалісти з управлінського обліку, щзб допомогти організація створювати, реалізовувати $i$ вдосконалювати їхні стратегії. Модель компетениій охоплює чотири сфери: спеціалізовані та ділові навички, комунікабельність і лідерство.

Досліджено застосування Глобальних принщипів у сферах діяльності: трансформація витрат і управління ними, зовнішня звітність, фінансова стратегія, внутрішній контроль, оиінка ефективності інвестицій, управління і бюджетний контроль, иіни, знижки і рішення щзодо продуктів, управління проектами, дотримання нормативно-правових актів, управління ресурсами, управління ризиками, стратегічний податковий контроль, управління фінансами, внутрішній аудит.

Ключові слова: управлінський облік, принципи, глобальні принципи управлінського 
обліку, інформація, релевантність, вартість, довіра.

Табл.: 2. Рис.: 7. Літ.: 7.

\title{
GLOBAL PRINCIPLES OF MANAGERIAL ACCOUNTING AND THEIR APPLICATIONS AT ENTERPRISES
}

\author{
LEPETAN Inna, \\ PhD in Economics, Associate Professor, \\ Associate Professor of Accounting Department, \\ Vinnytsia National Agrarian University
}

(Vinnytsia)

\begin{abstract}
The article describes the list and essence of accounting principles and focuses on the principles of accounting, since not all generally accepted accounting principles are suitable for application in management accounting. The basic principles of management accounting are combined with the integration of different aspects, which are distinguished by different scientists.
\end{abstract}

The Global Principles of Management, developed by international organizations and identifying best practices in accounting that help to make complex decisions that deliver value, are described in more detail.

The article describes the components of the principles and ways of their application. Attention is paid to the principle "Communication generates influential information", which means that management accounting begins and ends with communication. The main purpose of this principle is to make effective decisions about the strategy and its implementation at all levels.

The "Information is relevant" principle directs management records to provide managers with relevant information when necessary, identifying past, current, and future information, including financial and non-financial data from internal and external sources. This includes social, environmental and economic data. The purpose of this principle is to provide the enterprise with information support in planning and developing strategy, tactics and their implementation.

The principle of "Impact analysis", management accounting links the strategy of the organization with its business model. This principle helps to work out different scenarios to understand their impact on value creation and conservation. The main purpose of this principle is to simulate different scenarios that demonstrate cause and effect relationships between activity factors and outcomes.

The purpose of the principle of "Smart management builds trust" is formulated as the need to actively manage relationships and resources to protect the financial and non-financial assets of the company, its reputation and value.

Attention is drawn to the core competencies that management accounting professionals must possess to help an organization create, implement, and refine their strategies. The competency model covers four areas: specialized and business skills, communication skills and leadership.

The application of Global Principles in the fields of activity: cost transformation and management, external reporting, financial strategy, internal control, evaluation of investment efficiency, management and budgetary control, prices, discounts and product decisions, project management, regulatory compliance, management resources, risk management, strategic tax control, financial management, internal audit.

Keywords: managerial accounting, principles, global principles of managerial accounting, information, relevance, value, trust.

Tab.: 2. Fig.: 7. Lit.: 7. 


\title{
ГЛОБАЛЬНЫЕ ПРИНЦИПЫ УПРАВЛЕНЧЕСКОГО УЧЕТА И ИХ ПРИМЕНЕНИЕ НА ПРЕДПРИЯТИЯХ
}

\author{
ЛЕПЕТАН И.М., \\ кандидат экономических наук, \\ доцент кафедры бухгалтерского учета, \\ Винницкий национальный аграрный университет
} (2. Винница)

В статье раскрыто перечень и сущность принцииов бухгалтерского учета $и$ сосредоточено на принципах именно управленческого учета, поскольку не все общепринятые принципы бухгалтерского учета подходят для применения в управленческом учете. Систематизированы основные принципы управленческого учета с объединением по различным аспектам, выделенных различными учеными.

Более подробно раскрыто Глобальные принцииы управленческого учета, разработанные международными организачиями и которые определяют передовую практику бухгалтерского учета, способствует принятию сложных решений, обеспечиваюших устойчивую ценнность.

В статье описано составляющие принщипов и пути их применения. Уделено внимание принципа «Коммуникация порождает информацию, имеющую влияние», который означает, что управленческий учет начинается и завершается общением. Основной целью этого принципа является принятие эффективных решений о стратегии и ее реализации на всех уровнях.

Принщип «Информаџия является релевантной» направляет управленческий учет на обеспечение руководителей релевантной информацией тогда, когда это необходимо, обнаруживает прошлую, текущую, будущую информацию, в том числе финансовые $и$ нефинансовые данные из внутренних и внешних источников. Сюда входят сочиальные, экологические и экономические данные. Целью этого приниипа является предоставление предприятию информационной поддержки при планировании и разработке стратегии, тактики и их реализации.

Принщипу «Анализируется влияние на стоимость» управленческий учет увязывает стратегию организации с ее бизнес-моделью. Этот принции помогает обрабатьвать различные сценарии с иелью понимания их влияния на создание и сохранение стоимости. Основной иелью этого приниипа является моделирование различных сценариев, демонстрирующих причинно-следственные связи между факторами деятельности $u$ результатами.

Цель принципа «Умное управление выстраивает доверие» сформулирована как необходимость активно управлять отношениями и ресурсами для защиты финансовых $и$ нефинансовых активов компании, ее репутации и стоимости.

Обращено внимание на основные компетенции, которыми должны обладать специилисты по управленческому учету, чтобы помочь организация создавать, реализовывать и совершенствовать их стратегии. Модель компетенций охватывает четыре сферы: специализированные и деловые навыки, коммуникабельность и лидерство.

Исследовано применение Глобальных принципов в сферах деятельности: трансформаџия затрат и управления ими, внешняя отчетность, финансовая стратегия, внутренний контроль, оценка эффективности инвестиций, управления и бюджетный контроль, скидки и решение относительно продуктов, управление проектами, соблюдение нормативно-правовых актов, управление ресурсами, управления рисками, стратегический налоговый контроль, управление финансами, внутренний аудит. 
Ключевые слова: управленческий учет, принципы, глобальные принципы управленческого учета, информация, релевантность, стоимость, доверие.

Табл.: 2. Рис.: 7. Лит.: 7.

Постановка проблеми. Управління господарського діяльністю $\epsilon$ складним і комплексним процесом, важливою компонентою якого є система інформаційного забезпечення - управлінський облік. Основною метою управлінського обліку $є$ допомога менеджменту підприємства в досягненні стратегічних цілей підприємства. Тому результативність суб'єкта господарювання безпосередньо залежить від рівня розвитку управлінського обліку. Сучасна система управлінського обліку включає чимало процедур, вибір яких залежить від цілей управління, здатності оперативно реагувати на зміну зовнішніх і внутрішніх чинників, можливості коригувати неактуальні цілі, прогнозувати ситуацію на майбутнє. Проте, вони повинні відповідати певним управлінського обліку присвячено праці як зарубіжних, так і вітчизняних авторів,зокрема: В.Б. Івашкевича[2], О.С. Красова [3], Л.В. Нападовської [4],О.С. Ніколаєвої [6], Т.В. Шишкової [6] та інших. У наукових працях зазначених вчених приведено власний підхід до переліку принципів управлінського обліку, щодо якого кожен автор має власне бачення. Це сприяло проведенню критичного аналізу та розробці базових принципів управлінського обліку та його основоположних припущень.

Формування мети статті дослідження. Метою статті $є$ дослідження глобальних принципів управлінського обліку, визначити умови та перспективи ix застосування на вітчизняних підприємствах.

Виклад основного матеріалу дослідження. Управлінський облік організовується та проводиться для задоволення внутрішніх потреб керівництва, при цьому включає як фінансову, так і не фінансову інформацію, тому виникає проблема того, що не всі загальноприйняті принципи бухгалтерського обліку підходять до управлінського обліку, також є потреба у визначенні додаткових принципів. Відмічається, що основним принципом управлінського обліку є його орієнтація на задоволення інформаційних потреб управління, рішення задач внутрішньофірмового менеджменту різного рівня прав і відповідальності. При цьому інформація повинна випереджати прийняті рішення [2].

Принцип бухгалтерського обліку - це правило, яким слід керуватися при вимірюванні, оцінці та реєстрації господарських операцій і при відображенні їх результатів у фінансовій звітності1. Тобто принципи управлінського обліку - це базові засади, які є основою організації та ведення управлінського обліку.

Це означає, що до управлінського обліку доцільно приймати й інші принципи. Отже, автором систематизовано наступні базові принципи управлінського обліку, що наведені у табл. 1. 


\section{Базові принципи управлінського обліку}

\begin{tabular}{|c|c|}
\hline Джерело & Принципи, характеристика \\
\hline \multirow[t]{7}{*}{$\begin{array}{l}\text { Нападовська } \\
\text { Л.В. [4] }\end{array}$} & $\begin{array}{l}\text { Принцип методологічного плюралізму - переважна більшість економічних проблем можу } \\
\text { бути вирішена більш плідно на основі методологічних прийомів різних дисциплін, ніж це } \\
\text { можна зробити на рівні кожної з них окремо. }\end{array}$ \\
\hline & $\begin{array}{l}\text { Орієнтація обліку на досягнення стратегічних цілей підприємства - приймаючи найбільш } \\
\text { вигідне поточне рішення, враховуючи всі можливі альтернативи на різних рівнях управління, } \\
\text { пріоритетними слід вважати стратегічні цілі підприємства. }\end{array}$ \\
\hline & $\begin{array}{l}\text { Принцип результативності - при здійсненні будь-яких видів діяльності необхідно постійно } \\
\text { порівнювати затрати з отриманим доходом у результаті діяльності, при цьому доходи завжди } \\
\text { повинні перевищувати затрати. }\end{array}$ \\
\hline & $\begin{array}{l}\text { Принцип відповідальності за прийняття рішень - за результати, які є наслідком прийнятих } \\
\text { рішень на кожному рівні управління, відповідає конкретна особа. }\end{array}$ \\
\hline & $\begin{array}{l}\text { Принцип комплексності - управлінський облік базується на комплексній інформації, незалежно } \\
\text { від того, в якій системі ця інформація виникла і яка вона: якісна чи кількісна, зовнішня чи } \\
\text { внутрішня, фінансова чи не фінансова. }\end{array}$ \\
\hline & $\begin{array}{l}\text { Принцип «різна собівартість для різних цілей» - грунтується на використанні різних видів } \\
\text { собівартості для досягнення різних цілей. }\end{array}$ \\
\hline & $\begin{array}{l}\text { Принцип економічності - затрати на створення системи управлінського обліку не повинні } \\
\text { перевищувати отриману вигоду від її використання. }\end{array}$ \\
\hline \multirow[t]{3}{*}{$\begin{array}{l}\text { Красова } \\
\text { O.C. [3] }\end{array}$} & $\begin{array}{l}\text { Принципи, обумовлені вимогами бухгалтерського обліку - визначають основні методологічні } \\
\text { підходи до визначення суті управлінського обліку }\end{array}$ \\
\hline & $\begin{array}{l}\text { Принципи, що формують склад і процедури ведення управлінського обліку - визначають } \\
\text { перелік об’єктів спостереження, їх класифікаційні характеристики і одиниці виміру, } \\
\text { включаючи інформацію нефінансового характеру, процедури моніторингу господарських } \\
\text { операцій, що здійснюються на підприємстві, в реальному масштабі часу, перелік показників } \\
\text { внутрішньої звітності за короткі проміжки часу. }\end{array}$ \\
\hline & $\begin{array}{l}\text { Принципи, що визначають напрями і способи обліку в конкретних ситуаціях управління } \\
\text { господарським процесом - орієнтують систему управлінського обліку на використання } \\
\text { специфічних прийомів узагальнення інформації з метою обгрунтування управлінських рішень. } \\
\text { До таких принципів відносяться: періодичність, господарського циклу, облік витрат за } \\
\text { процесами діяльності, відповідність доходів і витрат, оцінка результатів діяльності } \\
\text { структурних підрозділів. }\end{array}$ \\
\hline \multirow{5}{*}{$\begin{array}{l}\text { Ніколаєва } \\
\text { О.С., } \\
\text { Шишкова } \\
\text { Т.В. [6] }\end{array}$} & $\begin{array}{l}\text { Принцип підзвітності - управлінський облік надає інформацію, яка створює передумови } \\
\text { щодо можливості оцінити ступінь досягнення організацією поставлених завдань, а також } \\
\text { внесок іiі підрозділів в досягнення цих завдань. }\end{array}$ \\
\hline & $\begin{array}{l}\text { Принцип контрольованості - за допомогою управлінського обліку визначаються елементи } \\
\text { або різновиди діяльності, на які керівництво спроможне або не спроможне здійснювати } \\
\text { вплив, та оцінюються ризики і несприятливі фактори. }\end{array}$ \\
\hline & $\begin{array}{l}\text { Принцип взаємозв’язку - управлінський облік в умовах бізнесу, який постійно } \\
\text { ускладнюється, повинен мати доступ до внутрішніх і зовнішніх джерел інформації щодо } \\
\text { таких інтерактивних функцій, як маркетинг, виробництво, персонал, постачання і } \\
\text { фінансування. }\end{array}$ \\
\hline & $\begin{array}{l}\text { Принцип доречності (інформації) - управлінський облік повинний забезпечувати гнучкість в } \\
\text { процесі збору та обробки інформації. }\end{array}$ \\
\hline & $\begin{array}{l}\text { Принцип надійності (інформації) - інформація управлінського обліку повинна бути такої } \\
\text { якості, яка надає впевненості в ії надійності. Довіра користувача до інформації залежить від ії } \\
\text { джерела, цілісності та повноти. }\end{array}$ \\
\hline
\end{tabular}

Джерело: узагальнено автором на основі джерел [3, 4, 6]

Відповідно до ст. 4 Закону України «Про бухгалтерський облік та фінансову звітність в Україні» встановлено такі принципи, на яких грунтується бухгалтерський облік: обачності, повного висвітлення, автономності, 
послідовності, безперервності, нарахування й відповідності доходів і витрат, превалювання сутності над формою, історичної (фактичної) собівартості, єдиного грошового вимірника та періодичності [7]. Проте не всі принципи підходять для управлінського обліку, який включає як фінансові, так і не фінансові дані.

Для ефективного функціонування управлінського обліку компаніям потрібний міцний організаційний фундамент і здатність швидко реагувати при ухваленні управлінських рішень. При цьому впровадження універсальних принципів поза сумнівом допомогло б досягти бажаних результатів. Саме 3 цією метою дві найбільші організації в сфері управління і обліку CIMA і AICPA об'єдналися, щоб запропонувати компаніям всього світу, незалежно від сфери їх діяльності і розміру, універсальні принципи управлінського обліку.

Міжнародні принципи управлінського обліку були розроблені спільно 3 генеральними і фінансовими директорами, іншими фахівцями зі всього світу.

За підсумками проведення міжнародних консультацій щодо проекту розробки принципів в кінці жовтня 2014 р. CIMA і AICРА опублікували фінальний документ, в якому були представлені 4 основні принципи управлінського обліку [1]. Поняття «управлінський облік» у виданні розкривається як «процес отримання, аналізу, комунікації та використання фінансової і нефінансової інформації, релевантної для прийняття рішень, задля генерування і збереження» [1] .

Система управлінського обліку США, що використовується у виробничому процесі [3, с. 12], базується на трьох узагальнюючих принципах, які, в свою чергу, деталізовані відповідним чином (табл. 2).

\section{Принципи управлінського обліку США}

Таблиия 2

\begin{tabular}{|c|c|c|}
\hline $\begin{array}{l}\text { Обумовлені } \\
\text { вимогами } \\
\text { фінансового } \\
\text { обліку }\end{array}$ & $\begin{array}{c}\mathrm{Ti}, \text { які формують склад і процедури ведення } \\
\text { управлінського обліку }\end{array}$ & $\begin{array}{l}\text { Ti, які визначають напрями і } \\
\text { способи обліку в конкретних } \\
\text { ситуаціях управління } \\
\text { виробництвом }\end{array}$ \\
\hline $\begin{array}{l}\text { 1. Безперервність } \\
\text { діяльності } \\
\text { підприємства }\end{array}$ & $\begin{array}{l}\text { 1. Єдність одиниць вимірювання, які } \\
\text { використовуються в плануванні і обліку процесу } \\
\text { виробництва }\end{array}$ & $\begin{array}{l}\text { 1. Періодичність, яка в відтворює } \\
\text { виробничий та комерційний цикли }\end{array}$ \\
\hline 2. Доречність & $\begin{array}{l}\text { 2. Послідовність та багатократність використання } \\
\text { первинної та проміжної інформації }\end{array}$ & $\begin{array}{l}\text { 2. Облік затрат за процесами } \\
\text { діяльності підприємства }\end{array}$ \\
\hline 3. Суттєвість & $\begin{array}{l}\text { 3. Повнота і аналітичність, які забезпечують } \\
\text { вичерпною інформацією користувачів щодо } \\
\text { об’єктів обліку }\end{array}$ & $\begin{array}{l}\text { 3. Облік затрат на основі руху } \\
\text { продукту }\end{array}$ \\
\hline 4. Достовірність & $\begin{array}{l}\text { 4. Нормативний i бюджетний (кошторисний) } \\
\text { методи контролю за рухом виробництва, } \\
\text { зростанням затрат та результатами виробництва }\end{array}$ & $\begin{array}{l}\text { 4. Відповідність доходів і затрат на } \\
\text { основі тимчасової визначеності } \\
\text { факторів господарської діяльності }\end{array}$ \\
\hline $\begin{array}{l}\text { 5. } \text { Облік } \\
\text { собівартістю }\end{array}$ & $\begin{array}{l}\text { 5. Логічність формування показників внутрішньої } \\
\text { звітності, яка відтворює комунікативний зв'язок } \\
\text { між рівнями і об’єктами управління }\end{array}$ & $\begin{array}{lr}\text { 5.Визнання результатів } & \text { діяльності } \\
\text { структурних } & \text { підрозділів } \\
\text { підприємства } & \end{array}$ \\
\hline 6. Періодичність & - & - \\
\hline $\begin{array}{l}\text { 7. Відповідність } \\
\text { доходів і витрат }\end{array}$ & - & - \\
\hline
\end{tabular}

Джерело: [3] 
Принципи управлінського обліку були розроблені 3 метою надання допомоги організаціям подолати розрізненість та стимулювати інтегроване мислення, яке забезпечить більш ефективне прийняття рішень.

Отже, згідно з документом «Глобальні принципи бухгалтерського обліку» існують чотири принципи, що зосереджені на досягненні чотирьох основних цілей: вплив (комунікація породжує інформацію, що має вплив), релевантність (інформація $є$ релевантною), вартість (аналізується вплив на вартість), довіра (розумне керування вибудовує довіру) (рис. 1).

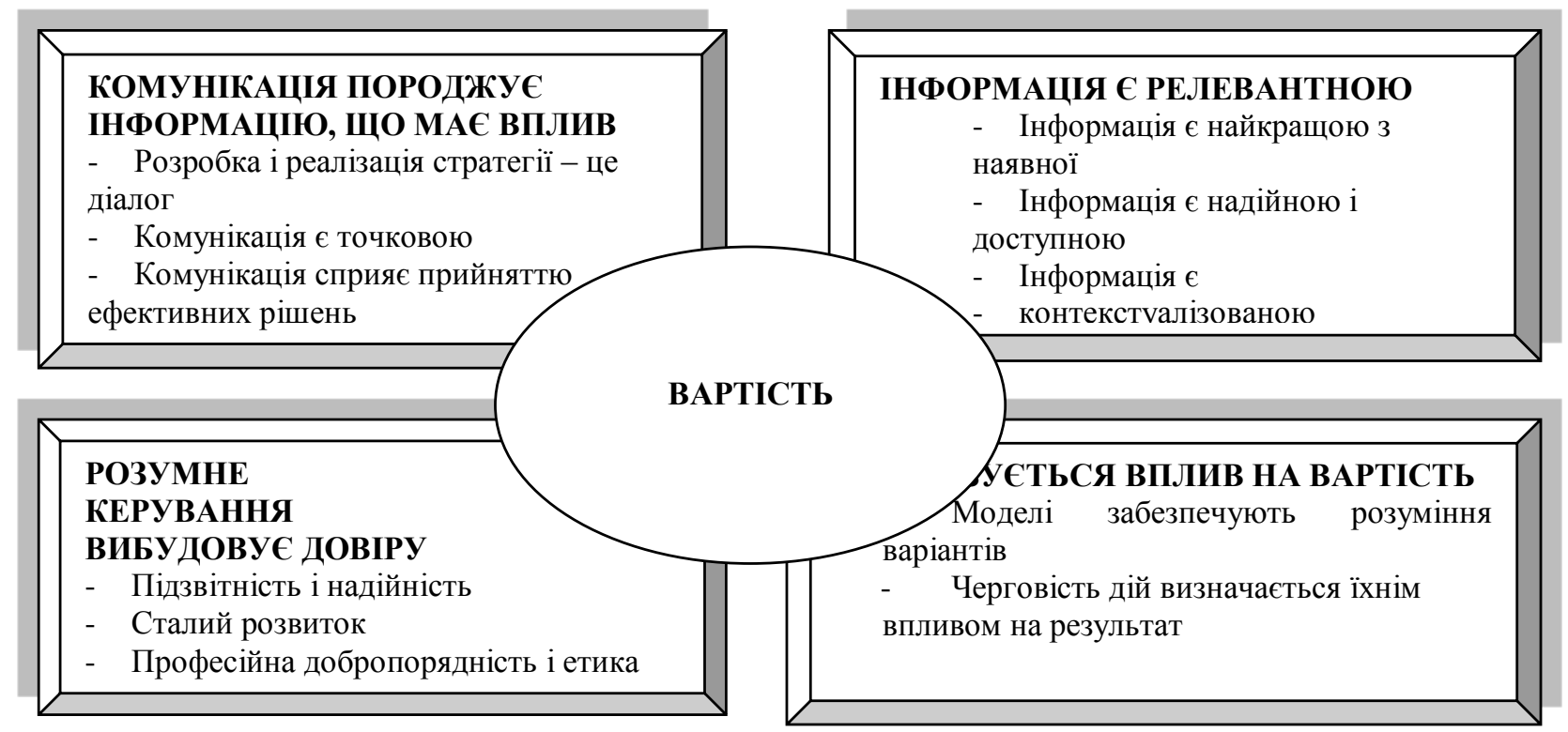

\section{Рис. 1. Глобальні принципи управлінського обліку}

Джерело: сформовано автором на основі [1]

Кожен 3 перерахованих принципів має своє пояснення. Так, принцип «Комунікація породжує інформацію, що має вплив» означає, що управлінський облік починається і завершується спілкуванням. Основною метою цього принципу є прийняття ефективних рішень про стратегію і їі реалізацію на всіх рівнях. Комунікація оптимізує процес прийняття рішень за рахунок передачі інформації на всіх етапах прийняття рішень. Належний обмін важливою інформацією в рамках управлінського обліку дозволяє долати розрізненість $\mathrm{i}$ сприяє інтегрованому мисленню. Наслідки дій в тій чи іншій сфері бізнесу стають більш зрозумілими i прийнятними, а їхнє коригування - більш ефективним (рис. 2). Принцип «Інформація $\epsilon$ релевантною» спрямовує управлінський облік на забезпечення керівників релевантною інформацією тоді, коли це необхідно, виявляє минулу, поточну, майбутню інформацію, зокрема фінансові та нефінансові дані з внутрішніх і зовнішніх джерел.

Релевантна інформація важлива для прийняття управлінських рішень тому, що вона містить дані, які слід використовувати для розрахунків при підготовці інформації для менеджерів. Релевантною буде та інформація, яка $є$ різною для різних альтернативних рішень, тобто вона буде пов'язана 3 конкретним 
рішенням. Несвоєчасна інформація не може бути релевантною, оскільки втрачає здатність впливати на прийняття рішень. Процес моделювання управлінських рішень полягає в порівнянні двох або більше можливих варіантів, для вибору кращого.

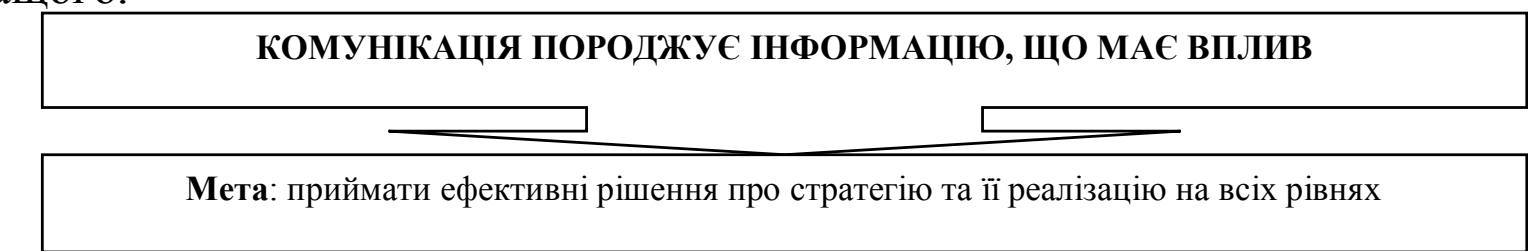

\begin{tabular}{|l|l|}
\hline $\begin{array}{l}\text { Розробка і реалізація } \\
\text { стратегії- це діалог }\end{array}$ & $\begin{array}{l}\text { Реалізація стратегії повинна обговорюватися на всіх рівнях } \\
\text { організації за участю всіх співробітників, щоб усунути } \\
\text { розрізненість в діях і мисленні. Це дозволяє чітко розмежувати } \\
\text { головні цілі та індивідуальні завдання. Управлінський облік } \\
\text { регулює обговорення, забезпечуючи йому основу у фактах і } \\
\text { експертних висновках щодо майбутніх процесів. }\end{array}$ \\
\hline
\end{tabular}

\begin{tabular}{|l|l|} 
Ківень деталізації і спосіб комунікації визначається 3 \\
Крахуванням користувачів інформації, специфіки рішення, що \\
обговорюєтья, і стилів прийняття рішень. Рівень фінансової \\
поінформованості аудиторії відомий, інформація надається в \\
доступній для розуміння формі. Необхідний результат \\
досягається за рахунок надійності, достовірності, своєчасності, \\
актуальності й доказовості інформації.
\end{tabular}

\begin{tabular}{|c|c|}
\hline & Управлінський облік також передбачає глибоке розуміння \\
\hline $\begin{array}{l}\text { Комунікація сприяє } \\
\text { прийняттю ефективних } \\
\text { рішень }\end{array}$ & $\begin{array}{l}\text { рішень, які необхідно прийняти організації. На основі такого } \\
\text { розуміння здійснюється збір та аналіз даних у відповідності до } \\
\text { Принципу «Інформація є релевантною». Фактична й аналітична } \\
\text { інформація є корисною лише тоді, коли вона здійснює } \\
\text { належний вплив і дозволяє організації створювати і захищати } \\
\text { вартість в довгостроковій перспективі. }\end{array}$ \\
\hline
\end{tabular}

\section{Рис. 2. Характеристика принципу «Комунікація породжує інформацію, що має вплив»}

Джерело: узагальнено автором на основі [1]

Сюди входять соціальні, екологічні та економічні дані. Метою цього принципу є надання підприємству інформаційної підтримки при плануванні та розробці стратегії, тактики та їхньої реалізації (рис. 3).

Принципом «Аналізується вплив на вартість» управлінський облік ув'язує стратегію організації з ії̈ бізнес-моделлю. Цей принцип допомагає опрацьовувати різні сценарії з метою розуміння їхнього впливу на створення та збереження вартості. За допомогою моделювання впливу можливостей та ризиків вимірюється їхній вплив на стратегічні результати і оцінюється ймовірність конкретного результату з точки зору створення, захисту чи зниження вартості. 


\section{ІНФОРМАЦІЯ С РЕЛЕВАНТНОЮ}

Мета: надавати організаціям підтримку при плануванні інформації, що необхідна для розробки стратегії й тактики ії реалізації

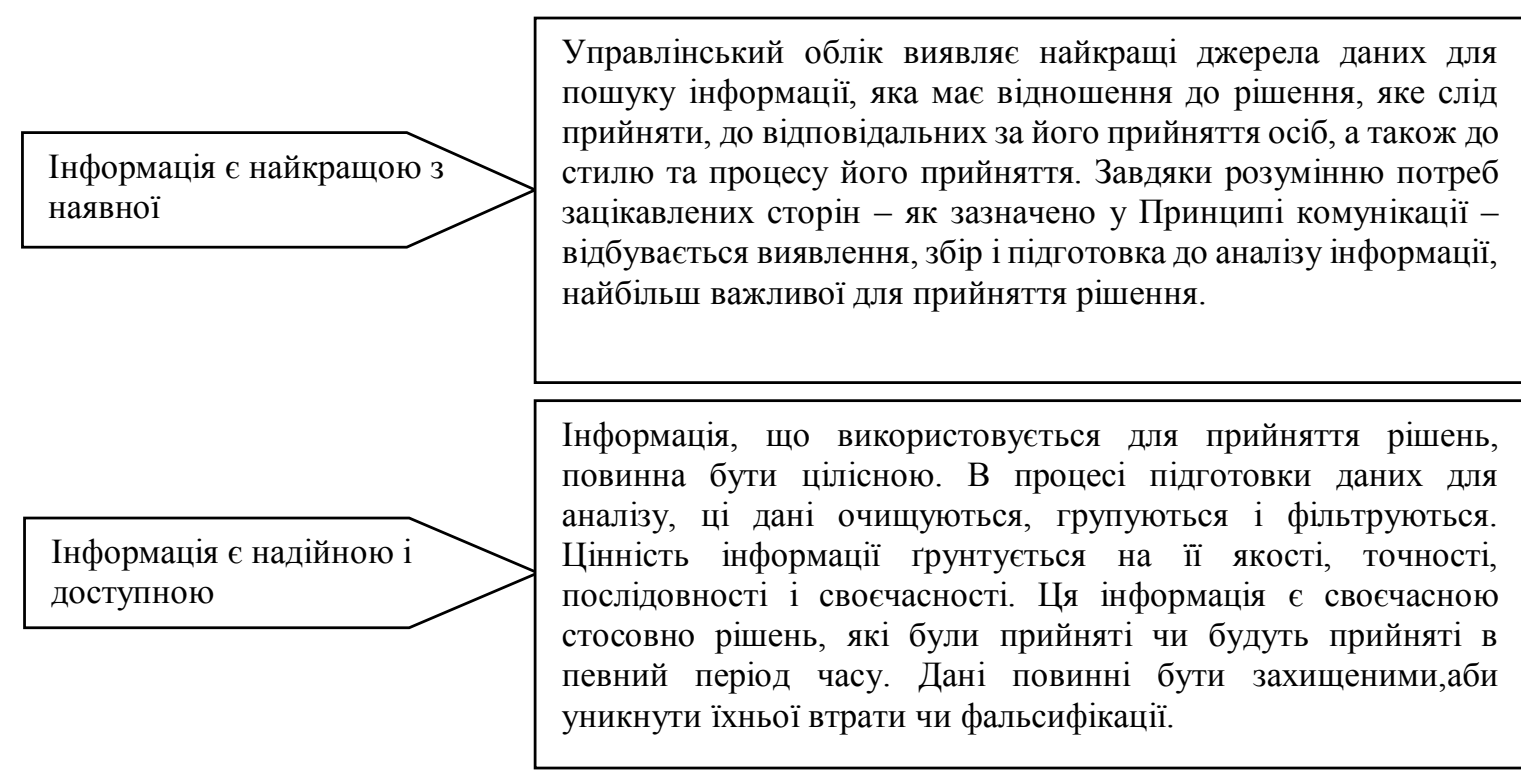

\begin{tabular}{|c|c|}
\hline & Інформація, яка застосовується в управлінському \\
\hline $\begin{array}{l}\text { Інформація є } \\
\text { контекстуалізованою }\end{array}$ & $\begin{array}{l}\text { прив’язаність до часу, необмеженість, різноманітність. } \\
\text { Навички обробки кількісної та якісної інформації в } \\
\text { управлінському обліку необхідні для того, щоб надавати } \\
\text { особам, відповідальним за прийняття рішень, дані за минулий } \\
\text { та поточний періоди, а також прогностичні дані. }\end{array}$ \\
\hline
\end{tabular}

\section{Puc. 3. Характеристика принципу «Інформація с релевантною» Дюерело: узагальнено автором на основі [1]}

Основною метою цього принципу є моделювання різних сценаріїв, що демонструють причинно-наслідкові зв'язки між чинниками діяльності i результатами (рис. 4).

Для створення моделей сценаріїв в управлінському обліку використовується релевантна інформація, що наведено вище, для створення моделей сценаріїв. Зусилля, що витрачаються для оцінки сценаріїв, повинні бути пропорційними до важливості рішення, що приймається. Цей принцип вимагає глибокого розуміння бізнес-моделі і макроекономічного середовища загалом.

Завдяки принципу «Розумне керування вибудовує довіру» процес прийняття рішень стає більш об'єктивним та створює оптимальний баланс серед короткострокових комерційних інтересів організації й довгострокової вартості для зацікавлених сторін, тим самим посилює довіру та створює ефект надійності. Визначена мета цього принципу сформульована як необхідність активно управляти відносинами та ресурсами для захисту фінансових і нефінансових 
активів компанії, їі репутації та вартості (рис. 5).

АНАЛІЗУСТЬСЯ ВПЛИВ НА ВАРТІСТЬ
Мета: моделювати різні сценарії, що демонструють причинно-наслідкові зв'язки між
чинниками виробництва і результатами

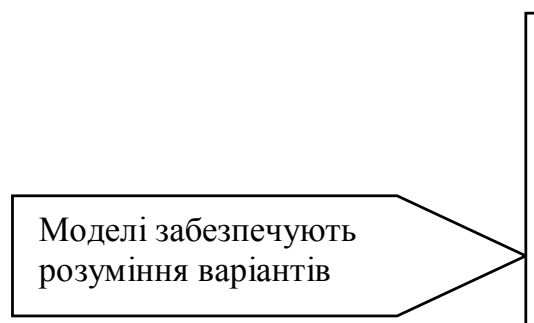

Моделі дозволяють організаціям розрахувати ймовірність успішного використання можливостей чи виникнення ризиків, а також вартість, що створюється чи знищується внаслідок цього.

Аналіз сценаріїв враховує зовнішнє середовище, в якому діють організації, зокрема:конкуренцію, законодавство і стан макроекономіки. Крім того, він бере до уваги поведінкові чинники, наприклад, знання про рушії витрат, ризиків і вартості. При наявності інформації про доступність необхідних ресурсів у довготривалій перспективі можна оцінити бізнесмодель на предмет іiї актуальності та стійкості на ринку.

Черговість дій визначається їхнім впливом на результат
Управлінський облік перетворює дані у висновки завдяки аналізу впливу сценаріїв, що розглядаються, на результати діяльності. Кожен 3 варіантів у різний спосіб впливає на структуру витрат організації, ризики i вартість. Сценарії дозволяють порівнювати різні варіанти i враховувати альтернативні витрати при прийнятті рішень.

Управлінський облік встановлює черговість дій на основі надійної логіки моделей сценаріїв, яка застосовується для обгрунтування кроків, що здійснюються. Глибоке розуміння стратегічних цілей організації, потреб зацікавлених осіб i узгоджених цілей дозволяє розподіляти дії, орієнтуючись на їхню значимість, аніж на супутні витрати.

\section{Рис. 4. Характеристика принципу «Аналізується вплив на вартість»} Джерело: узагальнено автором на основі [1]

Власне, шляхом впровадження та дотримання глобальних принципів управлінського обліку створюються умови, з одного боку, для зростання вартості бізнесу, а з іншого - для сталого розвитку економіки у тому розумінні, що це такий розвиток країн і регіонів, коли економічне зростання, матеріальне виробництво i споживання, а також інші види діяльності суспільства відбуваються в межах, які визначаються здатністю екосистем відновлюватися, поглинати забруднення і підтримувати життєдіяльність теперішніх та майбутніх поколінь [5].

За вимогою глобальних принципів, управлінський облік має докладно розуміти бізнес-модель господарюючого суб'єкта, ринкові умови та макроекономічне середовище.

Управлінський облік має посідати центральне місце в організації, бути на перетині фінансів і менеджменту та пропонувати структуровані рішення для неструктурованих проблем. 
Успіх організації будується на ефективному управлінському обліку. Глобальні принципи управлінського обліку «з'єднують точки», дозволяючи побачити прямий зв'язок між цілями компанії і методами управлінського обліку. Вони застосовуються в роботі зі спеціалістами 3 управлінського обліку (у відповідності до посадових повноважень) і можуть стосуватися: самих спеціалістів (фахівців), управління ефективністю організації, практики управлінського обліку.

\section{РОЗУМНЕ КЕРУВАННЯ ВИБУДОВУС ДОВІРУ}

Мета: активно управляти відносинами та ресурсами задля захисту фінансових і нефінансових активів підприємства, його репутації та вартості.
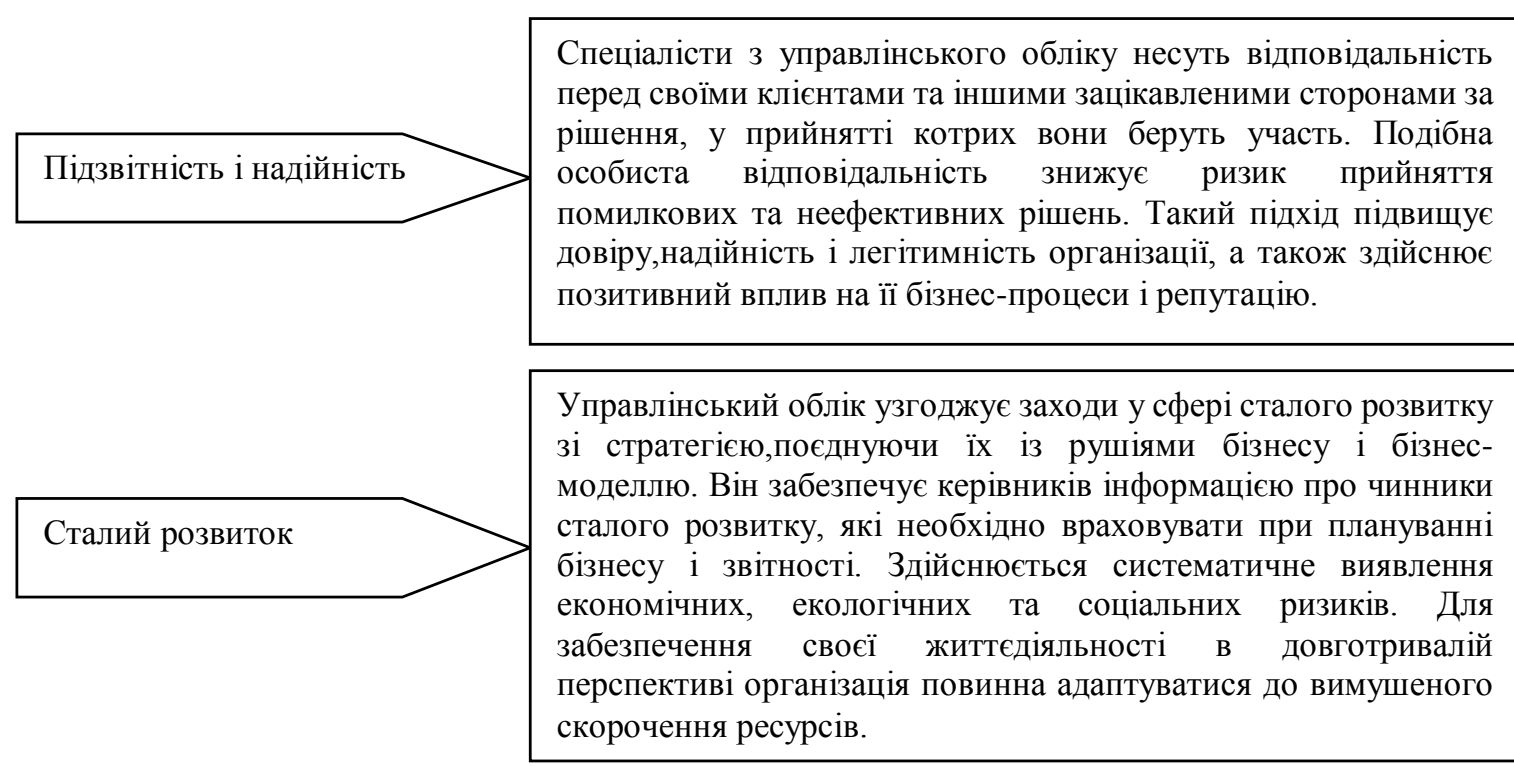

Посадові обов'язки повинні ретельно виконуватися Професійна дотриманням взятих зобов'язань. Належить за будь-яку ціну добропорядність і етика уникати надання недостовірної інформації чи даних, які можна витлумачити помилково. Необхідно суворо дотримуватися букви й духу законів, кодексів і норм.

\section{Рис. 5. Характеристика принципу «Розумне керування вибудовує довіру»}

Джерело: узагальнено автором на основі [1]

Автори глобальних принципів управлінського обліку приділяють величезну увагу компетенціям та досвідченості фахівців, які, застосовуючи принципи, повинні підтримувати й покращувати систему управління ефективністю підприємницької діяльності. Вказані особи повинні: а) застосовувати навички бухгалтерського і фінансового обліку; б) забезпечити застосування цих навичок в умовах бізнесу; в) впливати на рішення, дії та поведінку інших осіб; г) бути лідерами на різних рівнях організації (рис. 6).

Модель компетенцій охоплює чотири сфери: спеціалізовані та ділові 
навички, комунікабельність і лідерство. Кожна сфера, у свою чергу, поділяється на чотири професійні рівні: базовий, середній, передовий і експертний. Кожному рівню відповідає певний набір навичок, необхідних для професійного розвитку. Фахівці з управлінського обліку повинні прагнути до безперервного навчання $\mathrm{i}$ професійного розвитку. Вони мають бути об'єктивними, діяти етично i враховувати інтереси суспільства. Також вони повинні допомагати своїм колегам долати упередження,приймаючи і втілюючи в життя організаційні рішення на основі фактів, а також, за можливості, за допомогою об'єктивних рішень, що пройшли перевірку емпіричним шляхом.

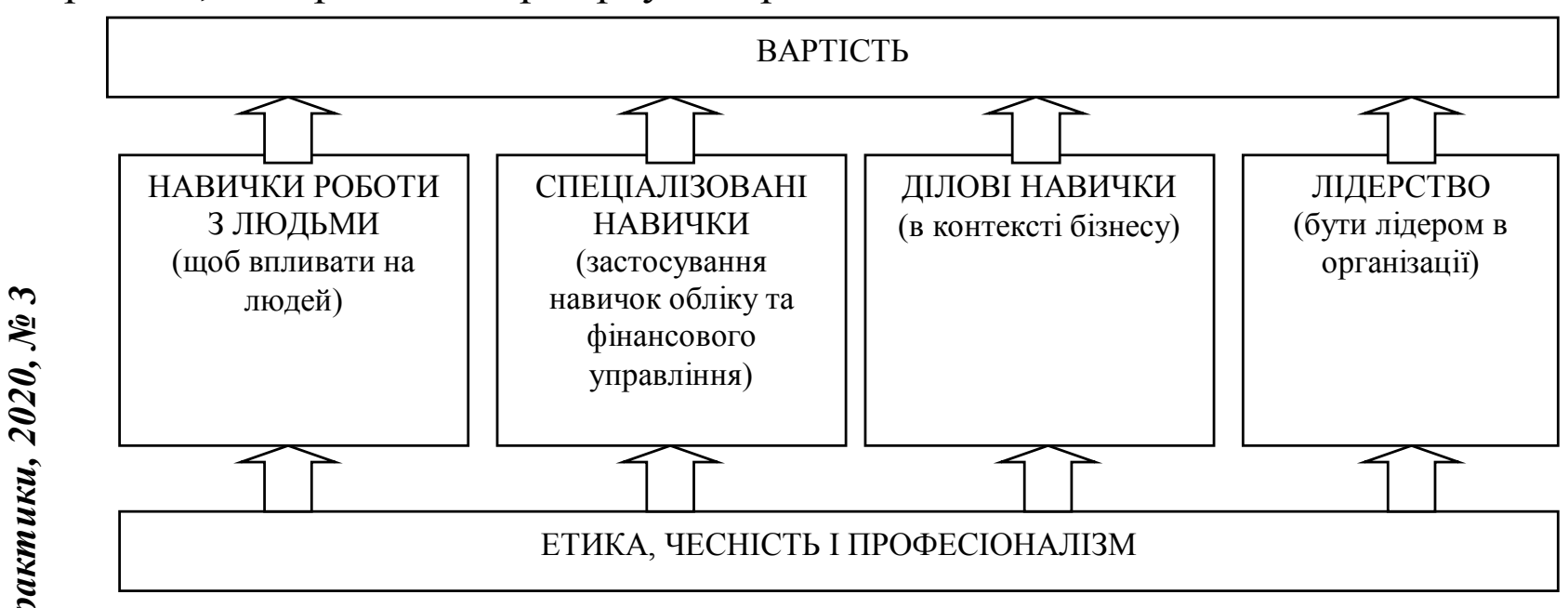

Рис. 6. Модель компетенцій фахівців з управлінського обліку Джерело: сформовано автором на основі [1]

Поєднання навичок бухгалтерського і фінансового обліку, розуміння бізнесу, аналітичних вмінь і відповідного досвіду означає, що до фахівців 3 управлінського обліку встановлюються вимоги бути практиками і мати досвід роботи в реальному бізнесі.

Застосування глобальних принципів управлінського обліку перш за все має здійснюватися в системі управління ефективністю, яка включає в себе стратегію, поточне планування, виконання планів та здійснення контролю всіх складових (рис. 7).

Глобальними принципами охоплюються практично всі сфери діяльності: трансформація витрат і управління ними, зовнішня звітність, фінансова стратегія, внутрішній контроль, оцінка ефективності інвестицій, управління і бюджетний контроль, ціни, знижки і рішення щодо продуктів, управління проектами, дотримання нормативно-правових актів, управління ресурсами, управління ризиками, стратегічний податковий контроль, управління фінансами, внутрішній аудит.

Застосування інструментарію глобальних принципів дозволяє в деталях здійснити процес перевірки дотримання кожного з принципів у будь-якій сфері діяльності.

Як свідчить досвід вітчизняних підприємств, формування цілісної 
системи управлінського обліку знаходиться на стадії становлення. Проте, для деяких підприємств це питання на часі. Тому $є$ нагода для спеціалістів 3 управлінського обліку оволодіти цими знаннями, щоб допомагати підприємствам створювати, реалізовувати та вдосконалювати їхні стратегії 3 урахуванням забезпечення економічної, соціальної та екологічної ефективності.

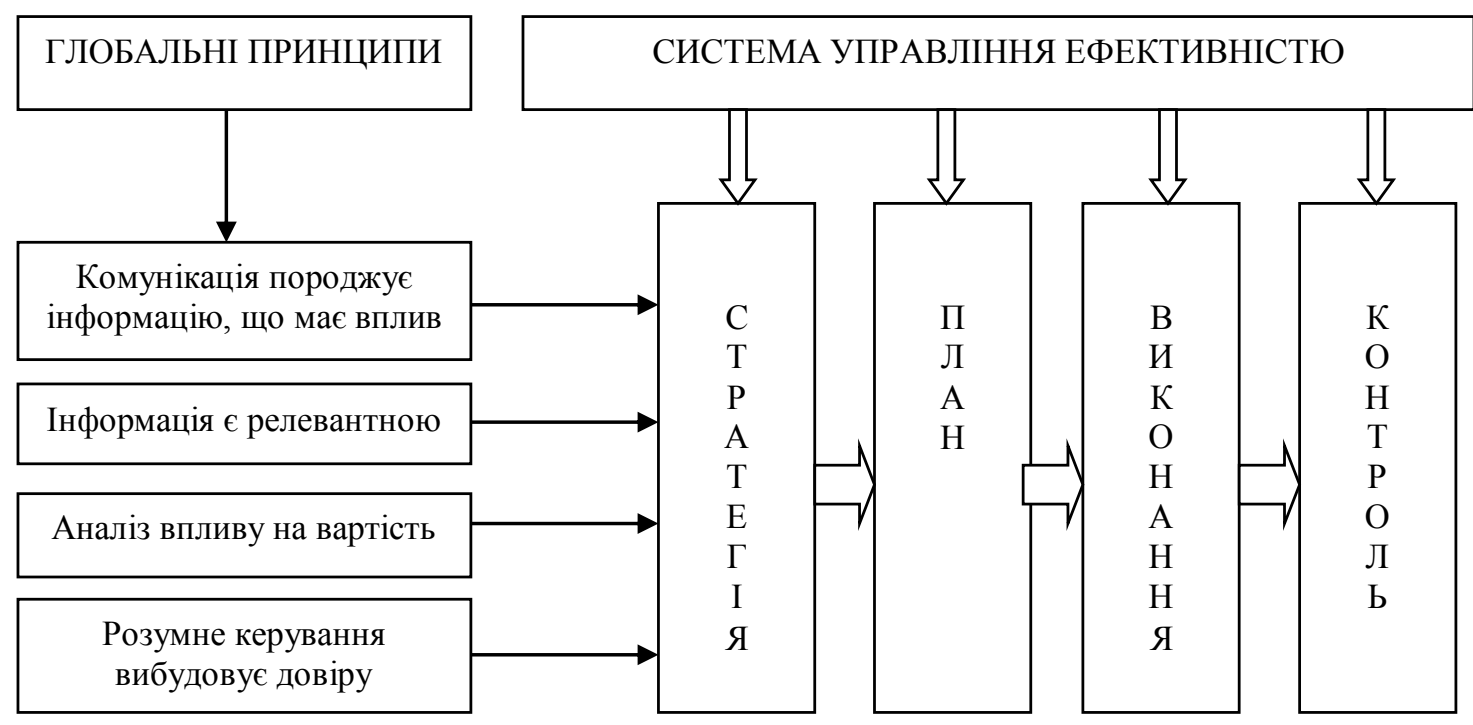

Puc. 7. Застосування Глобальних принципів управлінського обліку для системи управління ефективністю

Джерело: сформовано автором на основі [1]

Висновок. Глобальні принципи управлінського обліку, розроблені Американським інститутом сертифікованих публічних бухгалтерів (АICPA) та Привілейованим інститутом управлінських бухгалтерів (СIMA), увібрали в себе кращі практики зарубіжних країн, а тому заслуговують на визнання. Сформульовані в документі прозорі принципи є важливою складовою системи управлінського обліку та допомагають підприємствам досягти успіху в умовах сталого розвитку. На даний момент Глобальні принципи управлінського обліку носять рекомендаційний характер, але обов'язковість їх застосування представляється актуальною.

\section{Список використаних джерел}

1. Глобальні принципи управлінського обліку. Американський інститут сертифікованих публічних бухгалтерів; Інститут привілейованих управлінських бухгалтерів. URL: https://www.cgma.org/content/dam/cgma/resources/reports/dow nloadabledocuments/ukranian-full-gmaps-document.pdf.

2. Ивашкевич В. Б. Бухгалтерский управленческий учет. М.: Магистр: ИНФРА-М, 2011. 576 с.

3. Красова О.С. Управленческий учет в США. М. : ООО «Журнал «Горячая линия бухгалтера», 2006. 168 с.

4. Нападовська Л.В. Управлінський облік. К.: КНТЕУ, 2010. 648 с. 
5. Подборка материалов для прессы по Саммиту по устойчивому развитию 2015 года: Время глобальных действий в интересах людей и планеты. URL: http://www.un.org/sustainabledevelopment/ru/wp-contentuploads/sites/5/ 2015/08/FAQs_Sustainable_Development_Summit.pdf].

6. Управленческий учет: официальная терминология CIMA / Пер. с англ. О.Е. Николаевой, Т.В. Шишковой. М. ИД ФБК ПРЕСС, 2004. 200 с.

7. Закон України «Про бухгалтерський облік та фінансову звітність в Україні» від 06.07.1999 р. № 96-XIV. Верховна Рада України. 1999. URL: http:// https://zakon.rada.gov.ua/laws/show/996-14.

\section{References}

1. Hlobal'ni pryntsypy upravlins'koho obliku. Amerykans'kyj instytut sertyfikovanykh publichnykh bukhhalteriv; Instytut pryvilejovanykh upravlins'kykh bukhhalteriv [Global principles of management accounting. American Institute of Certified Public Accountants; Institute of Privileged Management Accountants]. cgma.org. Retrieved from https://www.cgma.org/content/dam/cgma/resources/reports /downloadabledocuments/ukranian-full-gmaps-document.pdf [in Ukrainian].

2. Ivashkevich, V. B. (2011). Buhgalterskij upravlencheskij uchet [Accounting Management Accounting]. Moscow: INFRA-M [in Russian].

3. Krasova, O.S. (2006). Upravlencheskij uchet $v$ SShA [Management Accounting in the United States]. Moscow: OOO «Zhurnal «Gorjachaja linija buhgaltera» [in Russian].

4. Napadovskaya, L.V. (2010). Upravlins'kyj oblik [Managerial Accounting]. Kyiv: KNTEU [in Ukrainian].

5. Podborka materialov dlja pressy po Sammitu po ustojchivomu razvitiju 2015 goda: Vremja global'nyh dejstvij v interesah ljudej i planet [Press kit for the 2015 Sustainable Development Summit: A Time for Global Action for People and the Planet]. un.org. Retrieved from http://www.un.org/sustainabledevelopment/ru/wpcontent/uploads/sites/5/2015/08/FAQs_Sustainable_Development_Summit.pdf [in Russian].

6. Nikolaev, O.E., \& Shishkova, T.V. (2004). Upravlencheskij uchet: oficial'naja terminologija CIMA [Management Accounting: CIMA Official Terminology] . Moscow: ID FBK- PRESS [in Russian].

7. Zakon Ukrayiny «Pro bukhhalters'kyy oblik ta finansovu zvitnist' v Ukrayini» [The Law of Ukraine "On Accounting and Financial Reporting in Ukraine". zakon.rada.gov.ua. Retrieved from http:// https://zakon.rada.gov.ua/laws/show/99614.

\section{Відомості про автора}

ЛЕПЕТАН Інна Михайлівна - кандидат економічних наук, доцент кафедри бухгалтерського обліку, Вінницький національний аграрний університет (вул. Сонячна, 3, м. Вінниця, 21008, e-mail: lepetan_inna@i.ua)

LEPETAN Inna - PhD in Economics, Associate Professor, Associate Professor 